\title{
Evaluation of outer dense fiber-1 and - 2 protein expression in asthenozoospermic infertile men
}

\author{
Silvia W. Lestari, ${ }^{1,3}$ Dwi A. Pujianto, ${ }^{1,3}$ Purnomo Soeharso, ${ }^{1,3}$ Evelyn Loanda² \\ ${ }^{1}$ Department of Medical Biology, Faculty of Medicine, Universitas Indonesia, Jakarta, Indonesia \\ 2 Department of Biochemistry, Faculty of Medicine, University of Atmajaya, Jakarta, Indonesia \\ ${ }^{3}$ Indonesian Reproductive Medicine Research and Training Centre (Ina-Repromed), Yasmin Infertility Clinic, Kencana Cipto \\ Mangunkumuso Hospital, Jakarta, Indonesia
}

\section{ABSTRAK}

Latar belakang: Sebagian besar penyebab ketidaksuburan laki-laki adalah rendahnya motilitas spermatozoa (astenozoospermia). Hingga saat ini, etiologi astenozoospermia pada tingkat molekuler belum banyak diketahui. Motilitas spermatozoa sangat ditentukan oleh struktur aksonem yang disusun mikrotubul dan didukung oleh protein outer dense fiber (ODF) dan fibrous sheath (FS). Penelitian ini bertujuan untuk menganalisis ekspresi protein ODF1 dan ODF2 pada spermatozoa pria yang tidak subur astenozoospermia dan kontrol pada pria yang subur normozoospermia.

Metode: Sampel semen astenozoospermia ( $n=18)$ diperoleh dari Laboratorium Andrologi Rumah Sakit Cipto Mangunkusumo Jakarta dan kontrol diperoleh dari donor laki-laki subur normozoospermia $(n=18)$. Motilitas semen dianalisis dengan computer-assisted sperm analysis (CASA). Semen selanjutnya dianalisis dengan Western blot dan imunositokimia menggunakan antibodi yang mengenali protein ODF1 dan ODF2.

Hasil: Analisis ekspresi protein ODF1 menunjukkan adanya pita dengan berat molekul (BM) $\sim 30 \mathrm{kDa}$ dan ODF2 dengan pita $B M \sim 85$ kDa. Rerata intensitas pita ODF1 dan ODF2 lebih rendah pada kelompok astenozoospermia (AG) dibanding kelompok normozoospermia (NG). Selain itu, kedua protein $O D F$ terlokalisasi tidak padat dan tidak merata pada $A G$, dibandingkan dengan NG. Motilitas spermatozoa kelompok $A G$ lebih rendah dibandingkan dengan kelompok $N G$ berdasarkan average path velocity (VAP) $=32,07 \pm 7,03$ vs $37,58 \pm 8,73 \mu \mathrm{m} /$ $d t k, p=0,455$; straight line velocity (VSL) $=24,17 \pm 6,90 \mathrm{vs}$ $27,61 \pm 4,50 \mu \mathrm{m} / d t k, p=0,317$ dan curvilinear velocity $(V C L)=$ $45,68 \pm 7,91$ vs $55,55 \pm 16,40 \mu \mathrm{m} / d t k, p=0,099$.

Kesimpulan: Terdapat penurunan ekspresi dan penyebaran lokalisasi difus protein ODF1 dan ODF2 pada AG dibandingkan dengan NG. Perbedaan ini mungkin menyebabkan gangguan motilitas spermatozoa.

\section{ABSTRACT}

Background: Most of male infertility are caused by defect in sperm motility (asthenozoospermia). The molecular mechanism of low sperm motility in asthenozoospermic patients has not been fully understood. Sperm motility is strongly related to the axoneme structure which is composed of microtubules and supported by outer dense fiber (ODF) and fibrous sheath (FS) protein. The objective of this study was to characterize the ODF (ODF1 and ODF2) expression in asthenozoospermic infertile male and control normozoospermic fertile male.

Methods: Asthenozoospermic samples ( $\mathrm{n}=18)$ were collected from infertile patients at Andrology Lab, Cipto Mangunkusumo Hospital Jakarta and control were taken from normozoospermic fertile donor $(\mathrm{n}=18)$. After motility analyses by computerassisted sperm analysis (CASA), semen were divided into two parts, for Western blot and for immunocytochemistry analysis. Antibody against ODF1 and ODF2 protein were used in both analyses.

Results: Analysis of ODF1 protein expression showed bands with molecular weight of $\sim 30 \mathrm{kDa}$ and ODF2 $\sim 85 \mathrm{kDa}$. The mean band intensity of ODF1 and ODF2 protein were lower in the asthenozoospermic group (AG) compared to normozoospermic group (NG). Moreover, both ODF proteins were less intense and less localized in the AG than NG. Sperm motility was lower in AG, compared to control NG, i.e. average path velocity $(\mathrm{VAP})=32.07 \pm 7.03$ vs $37.58 \pm 8.73 \mu \mathrm{m} / \mathrm{s}, \mathrm{p}=$ 0.455 ; straight line velocity (VSL) $=24.17 \pm 6.90$ vs $27.61 \pm$ $4.50 \mu \mathrm{m} / \mathrm{s}, \mathrm{p}=0.317$ and curvilinear velocity $(\mathrm{VCL})=45.68 \pm$ 7.91 vs $55.55 \pm 16.40 \mu \mathrm{m} / \mathrm{s}, \mathrm{p}=0.099$.

Conclusion: There is down-regulation of ODF1 and ODF2 protein expression and less-compact localization in AG sperm compared to the NG. These changes might have caused disturbances in the sperm motility as observed in this study.

Keywords: asthenozoospermia, male infertility, ODF1, ODF2

pISSN: 0853-1773 • eISSN: 2252-8083 • http://dx.doi.org/10.13181/mji.v24i2.998• Med J Indones. 2015;24:79-83

- Received 07 Jul $2014 \cdot$ Accepted 18 Jun 2015

Correspondence author: Silvia W. Lestari, ceepee_95@yahoo.com

Copyright @ 2015 Authors. This is an open access article distributed under the terms of the Creative Commons Attribution-NonCommercialShareAlike 4.0 International License (http://creativecommons.org/licenses/by-nc-sa/4.0/), which permits unrestricted non-commercial use, distribution, and reproduction in any medium, provided the original author and source are properly cited. 
Indonesia has $40 \%$ fertile couples of 200 million total population. Ten percents of those couples are infertile. Infertility is defined as inability to conceive after at least one year of unprotected intercourse. Male infertility reaches $40-50 \%$ of general infertility cases, ${ }^{1,2}$ with asthenozoospermia being one of the causes. ${ }^{3}$

Asthenozoospermia is a condition in which the number of motile spermatozoa moving straight is below the WHO normal reference values of 32\%. ${ }^{4}$ The decrease of sperm motility may be caused by sperm dysfunction, abstinence, partial obstruction of seminal tract, varicocele and genetic factor. ${ }^{5,6}$ The mechanism of sperm motility involves sliding action of microtubules in the axoneme of sperm tail. In the morphogenesis process that occurs during spermatogenesis in the testes, sperm tail formation involves proteins such as outer dense fiber (ODF) and fibrous sheath (FS). In addition, sperm motility cannot be separated from the process of sperm maturation in the epididymis. Sperm maturation is a process in which sperm achieves its ability to fertilize the egg, occurring in the proximal of epididymis. ${ }^{7}$ In relation to the role of epididymis in sperm maturation, Aitken, et $\mathrm{al}^{8}$ showed that there are differences of protein profile in the caput of epididymis compared to the cauda.

In addition, several studies have identified proteins that are expressed in the epithelium of the epididymal duct, including the ODF. The importance of ODF and FS in the formation of fully competent sperm cells is indicated by the presence of ODF and FS protein in the epididymis, ${ }^{9}$ in which sperm cells undergo maturation by interaction with proteins secreted in the epididymal lumen. ${ }^{7,9}$ Chen, et $\mathrm{al}^{10}$ showed that the expression of ODF1 was decreased significantly in asthenozoospermic men. The role of ODF protein in sperm motility has also been showen by ODF2 knock out mouse study. ${ }^{11}$

Until now, the expression of ODF protein in infertile men with asthenozoospermia is still largely unknown. Thus, in the present study we wanted to characterize the ODF expression in asthenozoospermic sperm and to give information about sperm motility disruption at molecular level. It is expected that this might help the clinician to diagnose and give an appropriate treatment to asthenozoospermic patients.

\section{METHODS}

Sperm were collected from male infertile patients with asthenozoospermia who came to Andrology Lab at Cipto Mangunkusumo General Hospital, namely asthenozoospermic group (AG) and from control male fertile donor with normozoospermia, namely normozoospermic group (NG). After motility analysis by computer-assisted sperm analysis (CASA), semen were divided into two parts, one part for Western immunoblotting and another part for immunocytochemistry analysis. The study was conducted from May 2013 to September 2014. The protocol of this study has been approved by the Ethics Committee of the Faculty of Medicine, Universitas Indonesia (No. 317/HS F1/ETIK/2013).

\section{Computer-assisted sperm analysis (CASA)}

Motility parameters were examined using CASA (Hamilton - Thorne v.12.4 Build 006A). Parameter settings have been optimized to assess human spermatozoa. The motility parameters were analyzed of average path velocity (VAP), straight line velocity (VSL) and curvilinear velocity (VCL). Distance visual field calibrated with a calibration slide (Leja) and the final setting was stored. Filming was set up as many as 30 shots per second, where each movement of the head of spermatozoa taken at least 25 points per second to form a circuit trace. VSL (the distance between the start point to the end point divided by the length of time the formation of traces of the circuit traces) and VCL (the amount of displacement at each distance divided by the length of time shooting the formation of a series of traces) were analyzed. The analyses were performed 10 times on each sample, then the average was taken as the VAP, VSL and VCL. Analysis was performed on 100 spermatozoa per analysis time.

\section{Western blotting}

Sperms were washed in phosphate buffered saline (PBS) and protein were extracted with sodium dodecyl sulphate (SDS) extraction buffer containing 10\% SDS, $0.375 \mathrm{M}$ Tris $\mathrm{HCl}$, sucrose and protease inhibitor. Sperm protein were separated by SDS-polyacrylamide gel ${ }^{12}$ and transferred to polyvinylidene difluoride (PVDF) membrane (Amersham, CA, USA). ${ }^{13}$ The membrane was blocked in 5\% dry milk in tris-buffered saline and tween 20 (TBST) (10 mM Tris/HCl 7.6, $150 \mathrm{mM}$ $\mathrm{NaCl}, 0.05 \%$ Tween 20 ), and incubated with antihuman ODF antibody (Santa Cruz Biotechnology, 
USA) diluted 1:200 in blocking solution for overnight in $4^{\circ} \mathrm{C}$. Membrane was washed in TBST three times of five minutes each and then incubated with a secondary antibody (anti-rabbit-Ig-G conjugated horse radish peroxidase -Horseradish peroxidase/HRP) diluted in 1:1000 in 3\% skim milk or $1 \%$ for one hour in room temperature. Complex antigen-antibody were detected by enhanced chemiluminescence (ECL) plus Western blot detection system (Amersham, CA, USA)

\section{Immunocytochemistry}

Sperm were washed in Percoll gradient, air dried onto poly-L-lysine slides and fixed with $4 \%$ formaldehyde then permeabelized with $0.2 \%$ triton X-100. Antibody incubation was performed with anti-ODF protein antiserum SA 963, diluted $1: 200$ in blocking solution in $4^{\circ} \mathrm{C}$ for overnight. For detection, a secondary antibody (anti-rabbit-Ig-G antibody) linked to fluorecein isothicyanate (FITC) was used. The distribution and localization of ODF signal were detected by convocal microscope (Zeiss, Vanadia).

\section{RESULTS}

The results showed that there were differences between the AG and NG. CASA analysis showed that VAP was $32.07 \pm 7.03 \mu \mathrm{m} / \mathrm{s}$ in $\mathrm{AG}$ and $37.58 \pm 8.73$ $\mu \mathrm{m} / \mathrm{s}$ in $\mathrm{NG}(\mathrm{p}=0.455)$; VSL were $24.17 \pm 6.90$ and $27.61 \pm 4.50 \mu \mathrm{m} / \mathrm{s}$ respectively $(\mathrm{p}=0.317)$; whereas VCL were $45.68 \pm 7.91$ and $55.55 \pm 16.40 \mu \mathrm{m} / \mathrm{s}$ $(p=0.099)$ (Figure 1). Based on CASA analysis, we could state that motility parameters i.e. VAP, VSL and VCL in AG were lower than NG.

Western blot analysis to define the protein expression of ODF1 and ODF2 in sperm of AG and NG showed band ( $\sim 30 \mathrm{kDa})$ of ODF1 protein expression and its intensity was lower in the $A G$ group compared to NG (Figure 2A and 2B). The ODF2 protein expression showed band of $\sim 85 \mathrm{kDa}$ with the intensity being lower in AG compared to NG significantly (Figure $3 \mathrm{~A}$ and $3 \mathrm{~B}$ ).

Immunocytochemical analysis showed the localization of ODF1 protein was in the neck and tail of spermatozoa in the NG. On the other hand, the localization of ODF1 protein in AG was less intense and the distribution was more diffuse compared to NG (Figure 4A and 4B). Different from ODF1, the localization of ODF2 protein in NG was in all over

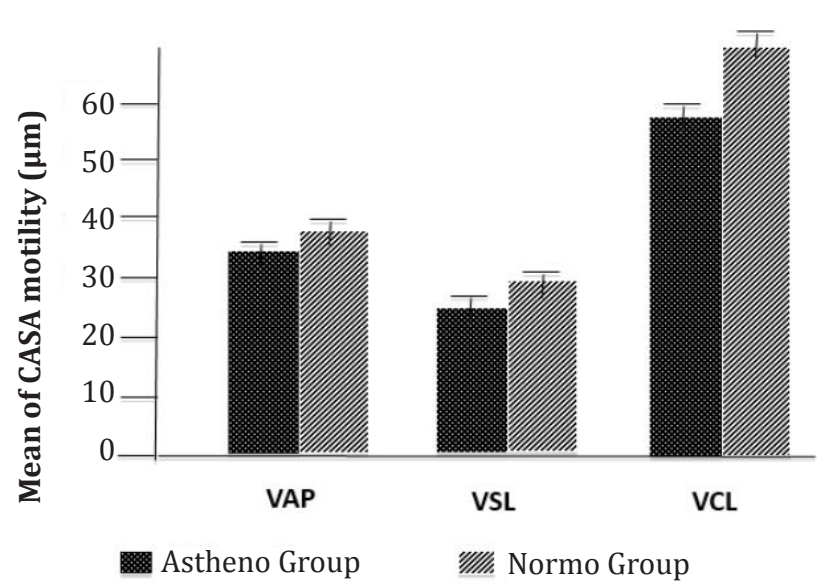

Figure 1. Result of sperm motility parameter of CASA analysis. AG indicates that the average of VAP, VCL and VSL were lower, compared to NG

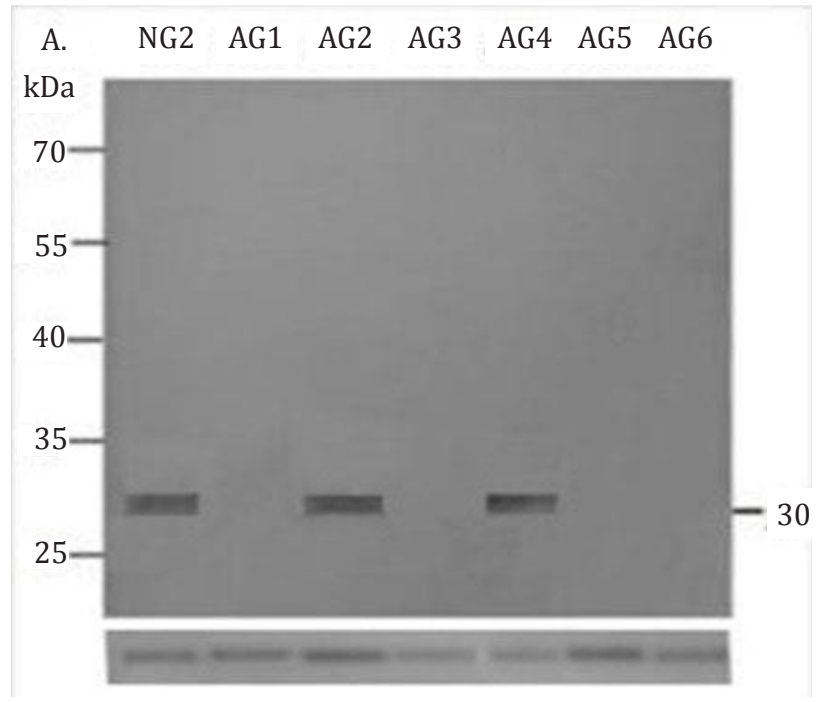

B.

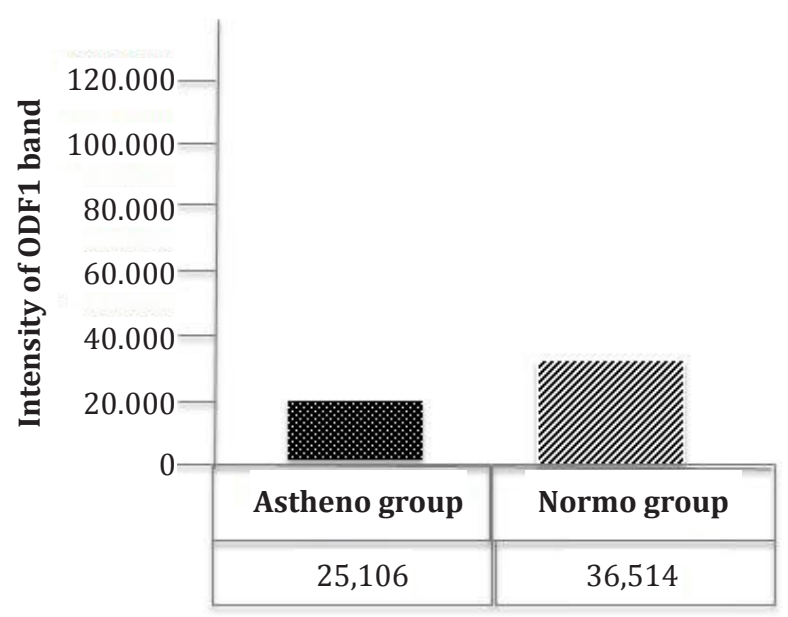

Figure 2. Western blot analysis to detect ODF1 protein in sperm of AG and NG. The result showed band ( $30 \mathrm{kDa})(\mathrm{A})$ and its intensity, (B) Tubulin was used as a house keeping protein. 
the head and tail of the sperm (head, middle piece and principal piece of tail) of spermatozoa (Figure $5 A)$. The ODF2 protein localization of AG was less intense and diffuse compared to NG (Figure 5B).

\section{DISCUSSION}

Based on CASA analysis, we observed motility parameters i.e. VAP, VSL and VCL in NG were higher than AG. Other study by Nayernia, et $\mathrm{al}^{14}$ whom generated mice with a targeted disruption of the gene SMCP by homologous recombination, indicated that the infertility of the male SMCP (-/-) mice on the 129/Sv background is due to reduced motility of the spermatozoa (asthenozoospermia)
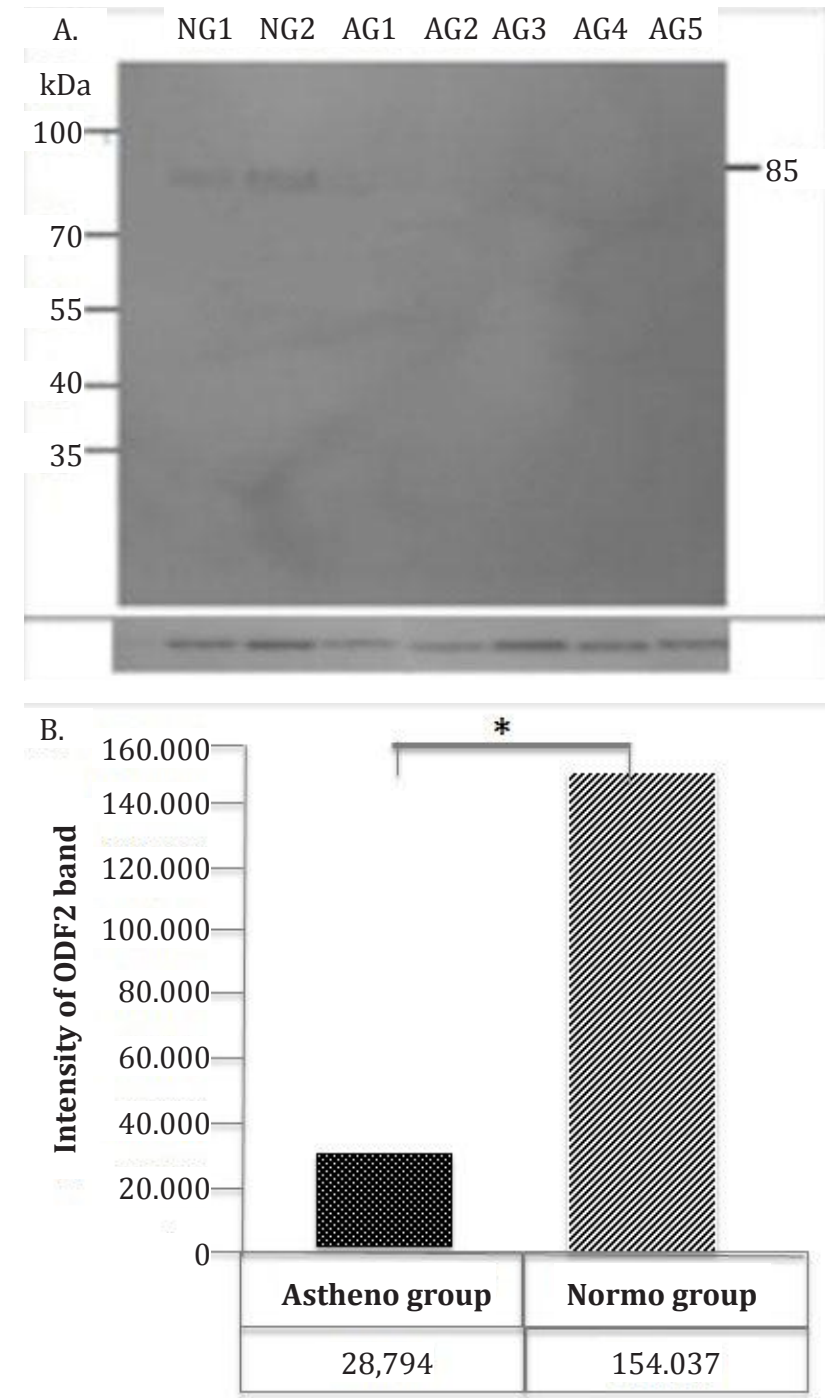

Figure 3. Western blot analysis to detect ODF2 protein in sperm of AG and NG. The result showed band ( $~ 85 \mathrm{kDa})(\mathrm{A})$ and its intensity (B). Tubulin was used as a house keeping protein as determined by CASA, as compared to wildtype spermatozoa (normozoospermia). ${ }^{14}$ The study showed differences of sperm motility parameter by CASA between normozoospermia and asthenozoospermia.

Besides those results, this study also supports previous finding that the most prominent proteins of human sperm ODF protein are the $30 \mathrm{kDa}$ ODF1 and $40-85 \mathrm{kDa}$ ODF2 protein. ${ }^{15,16}$ Our present study observed down-regulation of ODF1 and ODF2 in asthenozoospermic men compared to normozoospermic men. In line with our results,
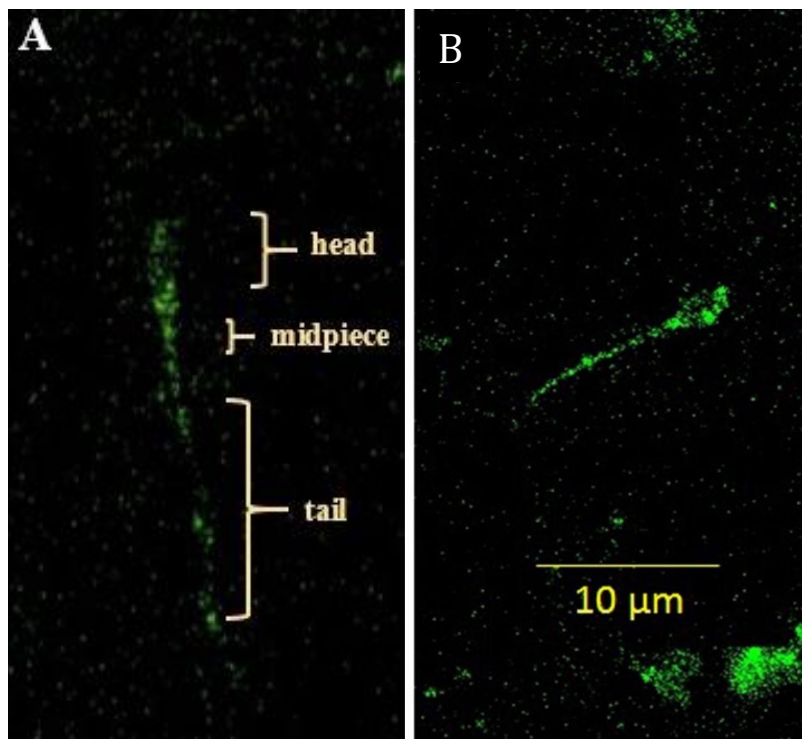

Figure 4. Immunocytochemistry analysis of ODF1 protein in sperm of $A G(A)$ and $N G(B)$
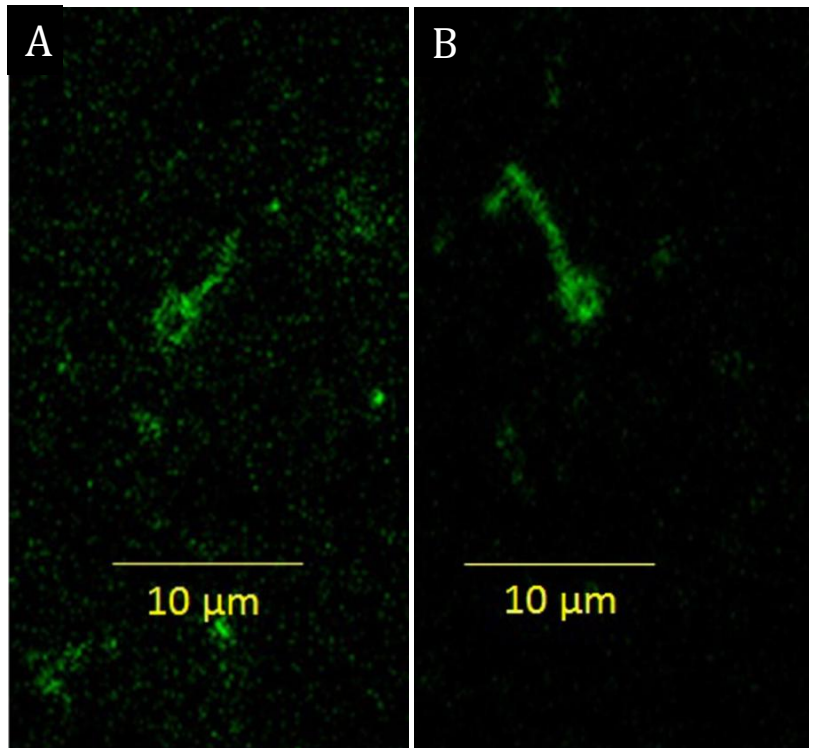

Figure 5. Immunocytochemistry analysis of ODF2 protein in sperm of AG (A) and NG (B) 
Chen, et $\mathrm{al}^{10}$ showed that the expression of ODF1 was decreased significantly in asthenozoospermic men. In addition, Chen, et $\mathrm{al}^{10}$ reported that in the ODF2 knock out mouse, the infertility was caused by the disruption of sperm tail formation and motility mechanism.

To the best of our knowledge, the present study was the first to show the different distribution of ODF2 protein in the asthenozoospermic patients compared to the normal sperm patients. Immunocytochemical analysis of this study also confirmed that the expression of ODF2 protein was different between normozoospermic and asthenozoospermic sample as indicated by different localization of ODF2 protein expression. Petersen, et $\mathrm{al}^{17}$ detected the ODF2 proteins over the middle piece of sperm tail and extends to about principal piece of sperm tail. The present study did not compare the sperm sample, whether those were from normozoospermic or asthenozoospermic samples.

In conclusion, we have shown that there were less active expression of ODF1 and ODF2 protein and less-compact localization in AG sperm compared to the NG. These results are probably due to disruptions in the ODF protein expression during maturation process at epididymis on asthenozoospermia sperm samples. The changes may, at least in part, have caused disturbances in the sperm motility. Further studies are needed to reveal the influence ODF expression level on sperm motility.

\section{Acknowledgments}

We would like to thank laboratory Department Biology, Faculty of Medicine, Universitas Indonesia for all facilities and provision that enable us to complete this study.

\section{Conflict of interest:}

This study was funded by research grant 2013 of Direktorat Riset Pengabdian Masyarakat, Universitas Indonesia.

\section{REFERENCES}

1. Moeloek N, Ahda Y. Perbandingan kemanjuran dan keamanan beberapa preparat FSH untuk stimulasi ovarium perempuan yang mengikuti program reproduksi berbantuan. Maj Kedokteran Indonesia. 2001;51(12):450-4. Indonesian.

2. Hamada A, Esteves SC, Agarwal A. Unexplained male infertility: potential causes and management. Human
Andrology. 2011;1:2-16.

3. Chuang WW, Lo KC, Lipshultz LI and Lamb DJ. Male infertility. In: Strauss JF, Barbieri RL, editors. Yen and Jaffe's reproductive endocrinology: phisiology, pathophysiology and clinical management. Philadelphia: Sanders. 2004. p. 669-71.

4. World Health Organization. WHO laboratory manual for the examination and processing of human semen. World Health Organization. 2010;5:21.

5. Gaur DS, Talekar M, Pathak VP. Effect of cigarette smoking on semen quality of infertile men. Singapore Med J. 2007;48(2):119-23

6. Gdoura R, Kchaou W, Chaari C, Znazen A, Keskes L, Rebai $\mathrm{T}$, et al. Ureaplasma urealyticum, Ureaplasma parvum, Mycoplasma hominis and Mycoplasma genitalium infections and semen quality of infertile men. BMC Infect Dis. 2007;7:129.

7. Cooper TG. Sperm maturation in the epididymis: a new look at an old problem. Asian J Androl. 2007;9(4):533-9.

8. Aitken RJ, Nixon B, Lin M, Koppers AJ, Lee YH, Baker MA. Proteomic changes in mammalian spermatozoa during epididymal maturation. Asian J Androl. 2007;9(4):554-64.

9. Sipilä P, Pujianto DA, Shariatmadari R, Nikkilä J, Lehtoranta M, Huhtaniemi IT, et al. Differential endocrine regulation of genes enriched in initial segment and distal caput of the mouse epididymis as revealed by genome-wide expression profiling. Biol Reprod. 2006;75(2):240-51.

10. Chen J, Wang Y, Xu X, Yu Z, Gui YT, Cai ZM. [Differential expression of ODF1 in human ejaculated spermatozoa and its clinical significance]. Zhonghua Nan Ke Xue. 2009;15(10):891-4. Chinese.

11. Tarnasky H, Cheng M, Ou Y, Thubdathil JC, Oko R, van der Hoorn FA. Gene trap mutation of murine Outer dense fiber protein-2 gene can result in sperm tail abnormalities in mice with high percentage chimaerism. BMC Developmental Biology. 2010;10:2-11.

12. Laemmli UK. Cleavage of structural proteins during assembly of the head of the bacteriophage T4. Nature. 1970;227(5259):680-5.

13. Towbin H, Staehelin T, Gordon J. Electrophoretic transfer of proteins from polyacrylamide gels to nitrocellulose sheets: procedure and some applications. Proc Natl Acad Sci USA. 1979;76(9):4350-4.

14. Nayernia K, Adham IM, Burkhardt-Göttges E, Neesen J, Rieche M, Wolf S, Sancken U, Kleene K, Engel W. Asthenozoospermia in mice with targeted deletion of the sperm-cystein-rich protein (Smcp) gene. Mol Cell Biol. 2002;22(9):3046-52.

15. Brohmann H, Pinnecke S, Hoyer-Fender S. Identification and characterisation of new cDNAs encoding outer dense fiber proteins of rat sperm. J Biol Chem. 1997;272(15):10327-32.

16. Hoyer-Fenders, Petersen C, Brohmann H dkk. 1998. Mouse Odf2 cDNAs consist of evolutionary conserved as well as highly variable sequences and encode outer dense fiber proteins of the sperm tail. Mol Reprod Dev. 1998;51:167-75.

17. Petersen C, Füzesi L, Hoyer-Fender S. Outer dense fibre proteins from human sperm tail: molecular cloning and expression analyses of two cDNA transcripts encoding protein of approximately $\sim 70 \mathrm{kDa}$. Mol Hum Reprod. 1999;5(7):627-35. 